\title{
Studi Perilaku Rantai Pasok Konstruksi Pada Proyek Pembangunan Gedung
}

\author{
Refdizalis $^{1}$, Taufika Ophiyandri ${ }^{2}$, Yervi Hesna ${ }^{3}$ \\ ${ }^{\mathbf{1}}$ Mahasiswa Teknik Sipil Universitas Andalas \\ ${ }^{2,3}$ Dosen Teknik Sipil Universitas Andalas \\ Correspondence Email: refdizalis@gmail.com
}

\begin{abstract}
Abstrak. Rantai Pasok Konstruksi adalah sebuah sistem pemasok, produsen, layanan transportasi, distributor dan penjual yang diciptakan untuk mengubah bahan dasar menjadi suatu produk konstruksi sehingga dapat dimanfaatkan oleh pengguna sesuai nilai yang dimintanya. Penelitian ini bertujuan untuk mengidentifikasi dan menganalisa pola rantai pasok material konstruksi serta menganalisa perilaku para pihak dalam rantai pasok konstruksi bangunan gedung. Penelitian ini dilakukan pada proyek bangunan gedung di Kabupaten Tanah Datar, dengan pendekatan kualitatif dan menggunakan analisis deskriptif yakni teknik analisis yang digunakan untuk menggambarkan atau mendeskripsikan kumpulan data wawancara dan hasil pengamatan. Hasil penelitian menunjukkan terdapat empat pola umum rantai pasok konstruksi yang digunakan yakni pola pekerjaan yang dikerjakan sepenuhnya oleh kontraktor utama, pola pekerjaan yang dilaksanakan oleh sub kontraktor termasuk penyediaan material, tenaga kerja dan peralatan, pekerjaan yang dilaksanakan oleh sub kontraktor spesialis dengan peralatan, material dan tenaga kerja disediakan oleh sub kontraktor spesialis, serta pola pekerjaan yang dilaksanakan oleh tenaga kerja dengan keahlian khusus, namun peralatan utama dan material masih diadakan langsung oleh kontraktor utama. Perilaku rantai pasok konstruksi dilakukan dengan mengkaji hubungan interaksi pelaku rantai pasok konstruksi meliputi analisa tentang sistem pengadaan yang digunakan, bentuk perjanjian, sistem pembayaran dan pengelolaan jaringan rantai pasok oleh kontraktor utama terhadap pelaku rantai pasok dibawahnya.
\end{abstract}

Kata Kunci: rantai pasok, pola, subkontraktor, kontraktor spesialis, supplier

\section{PENDAHULUAN}

Sektor Konstruksi menghasilkan infrastruktur baik yang merupakan publik goods seperti jalan, jembatan, pelabuhan, bendungan, jaringan irigasi maupun private goods seperti rumah hunian, hotel, shopping mall, pabrik dan lain sebagainya (Kirmanto, 2012). Pada proses produksi proyek konstruksi terdapat aliran informasi dan sumber daya yang mengalir ke seluruh bagian pihak yang terlibat dalam proyek konstruksi tersebut. Pihak -pihak yang terlibat dalam proses konstruksi secara tidak langsung akan membentuk rantai pasok (supply chain) yang kompleks. Perbedaan karakteristik produk dalam bidang konstruksi sektor gedung menyebabkan struktur dan perilaku rantai pasok konstruksi tiap-tiap proyek gedung memiliki pola tersendiri. Berdasarkan uraian diatas maka penulis tertarik untuk melakukan penelitian tentang studi Struktur dan Perilaku Rantai Pasok Konstruksi Pada Proyek Bangunan Gedung.

\section{Rantai Pasok Konstruksi}

Menurut Chopra dan Meindl (2007) dalam Maulani (2014) rantai pasok memiliki sifat yang dinamis namun melibatkan tiga aliran yang konstan, yaitu aliran informasi, produk dan uang yang bertujuan untuk memenuhi kebutuhan konsumen yang didalamnya terdapat aliran dan transformasi barang mulai dari bahan baku sampai ke konsumen akhir disertai dengan aliran informasi dan uang. Menurut Abduh (2012) Rantai Pasok Konstruksi adalah sebuah sistem pemasok, produsen, layanan transportasi, distributor dan penjual yang diciptakan untuk mengubah bahan dasar menjadi suatu produk konstruksi sehingga dapat dimanfaatkan oleh pengguna sesuai nilai yang dimintanya.

Bahagia (2012) menguraikan bahwa Sistem Rantai Pasok Pekerjaan Konstruksi pada hakikatnya tidak berbeda dengan Sistem Rantai Pasok Industri Manufaktur, maka rantai pasok konstruksi dapat disimpulkan sebagai suatu keterlibatan jaringan berbagai pihak atau organisasi (supplier, manufaktur, distributor dan retailer) yang sering berhubungan mulai dari hulu (upstream) hingga ke hilir (downstream) dalam bekerja sama untuk menyediakan material, peralatan dan sumber daya dari sumber kepada pengguna akhir.

\section{Pihak Dalam Rantai Pasok Konstruksi}

Dalam proyek konstruksi terdapat beberapa pihak yang berperan dalam siklus rantai pasok pekerjaan konstruksi seperti ditulis Toruan (2005) dalam Pribadi (2017) yaitu :

a. Pemasok jasa subkontraktor, adalah pemasok yang mampu mengerjakan sebagian atau yang sama dengan pekerjaan kontraktor utama atau pekerjaan lain yang tidak dapat dikerjakan oleh kontraktor utama dan tercatat dalam daftar Subkontraktor terseleksi. 
b. Supplier, adalah pemasok yang mampu mengadakan (mensuplai) satu atau beberapa jenis material/bahan dan peralatan yang diperlukan dalam pelaksanaan proyek termasuk pengadaan peralatan sewa yang tercatat dalam daftar pemasok material terseleksi.

c. Penyedia tenaga kerja atau mandor, adalah pemasok yang mampu mengadakan beberapa orang terampil maupun non terampil yang diperlukan bagi pelaksanaan proyek dan tercatat daftar mandor terseleksi.

Proses Rantai Pasok yang digunakan dalam standard internasional ISO 9001:2000 sebagaimana telah dimodifikasi oleh Toruan (2005) dalam Pribadi (2017) seperti diperlihatkan pada gambar 1 dibawah yang menggambarkan para pihak dalam rantai pasok disesuaikan dengan istilah sebagaimana dimuat dalam UndangUndang Nomor 2 Tahun 2017 tentang Jasa Konstruksi sebagai berikut :

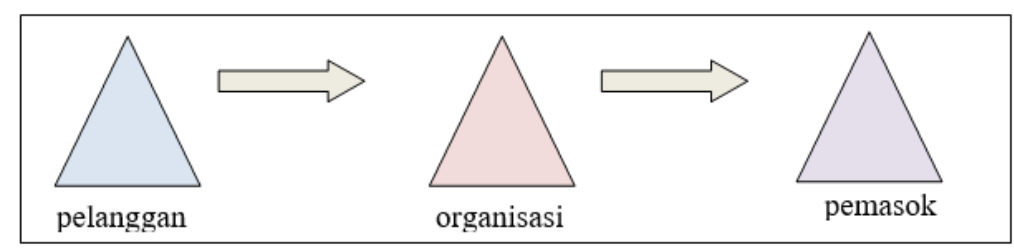

Sumber: Toruan, 2005

Gambar 1. Para Pihak dalam Siklus Rantai Pasok

a. Pelanggan adalah Pengguna Jasa. Pengguna Jasa adalah pemilik atau pemberi pekerjaan yang menggunakan Layanan Jasa Konstruksi

b. Organisasi adalah Penyedia Jasa. Penyedia Jasa adalah Pemberi Layanan Jasa Konstruksi. Hubungan hukum antara Pengguna Jasa dan Penyedia Jasa dalam penyelenggaraan Jasa Konsruksi diatur dengan sebuah dokumen kontrak.

c. Pemasok adalah mitra penyedia jasa. Mitra penyedia jasa memasok untuk penyedia jasa konstruksi, bisa sebagai subkontraktor, pemasok tenaga kerja, pemasok material atau pemasok peralatan.

\section{Struktur Rantai pasok Konstruksi}

Harland (1996) dalam Budiman (2017) mendefinisikan Struktur Rantai Pasok adalah susunan pengelolaan suatu jaringan bisnis yang saling berhubungan yang terlibat dalam penyediaan akhir paket-paket produk dan layanan yang diperlukan oleh konsumen akhir. Secara umum struktur sistem rantai pasok terdiri atas dua bagian, yaitu organisasi pada sisi "demand" dan organisasi pada sisi "supply". Kedua sisi organisasi tersebut dihubungkan oleh ikatan kontrak antara penanggung jawab utama kegiatan dengan penyedia jasa konstruksi. Penyedia jasa konstruksi yang langsung berhubungan dengan penanggung jawab kegiatan adalah penyedia jasa pelaksanaan konstruksi yaitu kontraktor, manajer konstruksi atau developer.

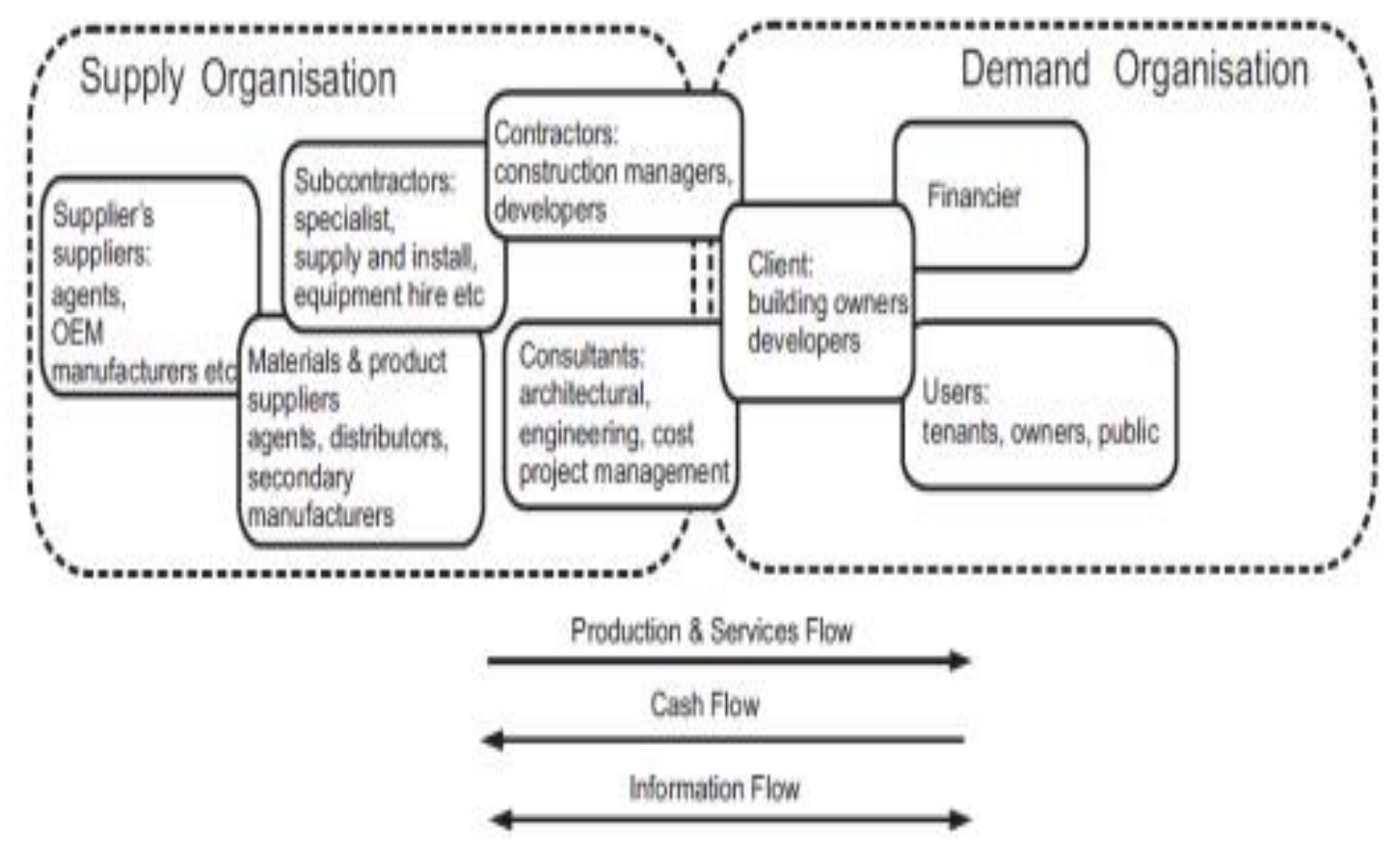

Sumber: Suraji, 2011

Gambar 2. Tipikal Rantai Pasok Konstruksi 


\section{Pola Rantai Pasok Konstruksi}

Analisa pola pola rantai pasok dilakukan berdasarkan tinjauan beberapa aspek dari tiap hubungan yaitu :

Tingkat hilir merupakan tinjauan terhadap hubungan kontraktor dengan owner dalam aspek : lingkup bisnis owner, karateristik produk konstruksi bangunan yang dibuat serta metoda kontrak yang dilakukan oleh owner.

Tingkat Organisasi Proyek merupakan aspek lingkup kerja yang diberikan oleh owner kepada kontraktor, dan aspek strategi produksi yang dilakukan oleh kontraktor dalam mengelola pekerjaan yang menjadi lingkup tanggung jawabnya.

Tingkat Hulu merupakan tinjauan terhadap hubungan kontraktor dengan pihak-pihak lain yang terlibat dalam proses produksi, terlepas dengan siapa hubungan kontrak terjadi antara pihak-pihak tersebut dengan pihak hilirnya.

Selanjutnya menurut Reini.D Wirahadikusumah dan Susilawati (2006) kerangka penyusunan pola rantai pasokan konstruksi dapat dilakukan berdasarkan dua struktur penyusunan yaitu struktur vertikal dan struktur horizontal.

\section{Perilaku Rantai Pasok Konstruksi}

Martin (1993) dalam Abduh (2012) menjelaskan Struktur Rantai Pasok dan perilaku (conduct) para pihak dalam jaringan Rantai Pasok Konstruksi akan mempengaruhi kinerja dari rantai pasok tersebut, hal ini sering disebut dengan pendekatan SCP atau Structure, Conduct and Performance. Sebagaimana terlihat dalam Gambar 3 menurut London (2008) dalam Abduh (2012), pasar akan berinteraksi dengan perilaku pihak-pihak yang terlibat dalam pasar tersebut, dalam hal ini struktur akan mempengaruhi perilaku, dan perilaku akan mempengaruhi struktur pasar juga. Interaksi ini akan terlihat dari bagaimana para pelaku rantai pasok terikat dalam proses pengadaan. Perilaku akan terlihat sekali terkait dengan bentuk perikatan yang terjadi, transaksi terjadi dan bagaimana pengelolaan dilakukan.

Maka dalam upaya melaksanakan pengelolaan rantai pasok konstruksi, maka gambaran akan strukturnya, perilakunya dan interaksinya harus dapat teridentifikasi dengan baik, agar pengelolaan dapat menghasilkan kinerja rantai pasok konstruksi yang diharapkan.

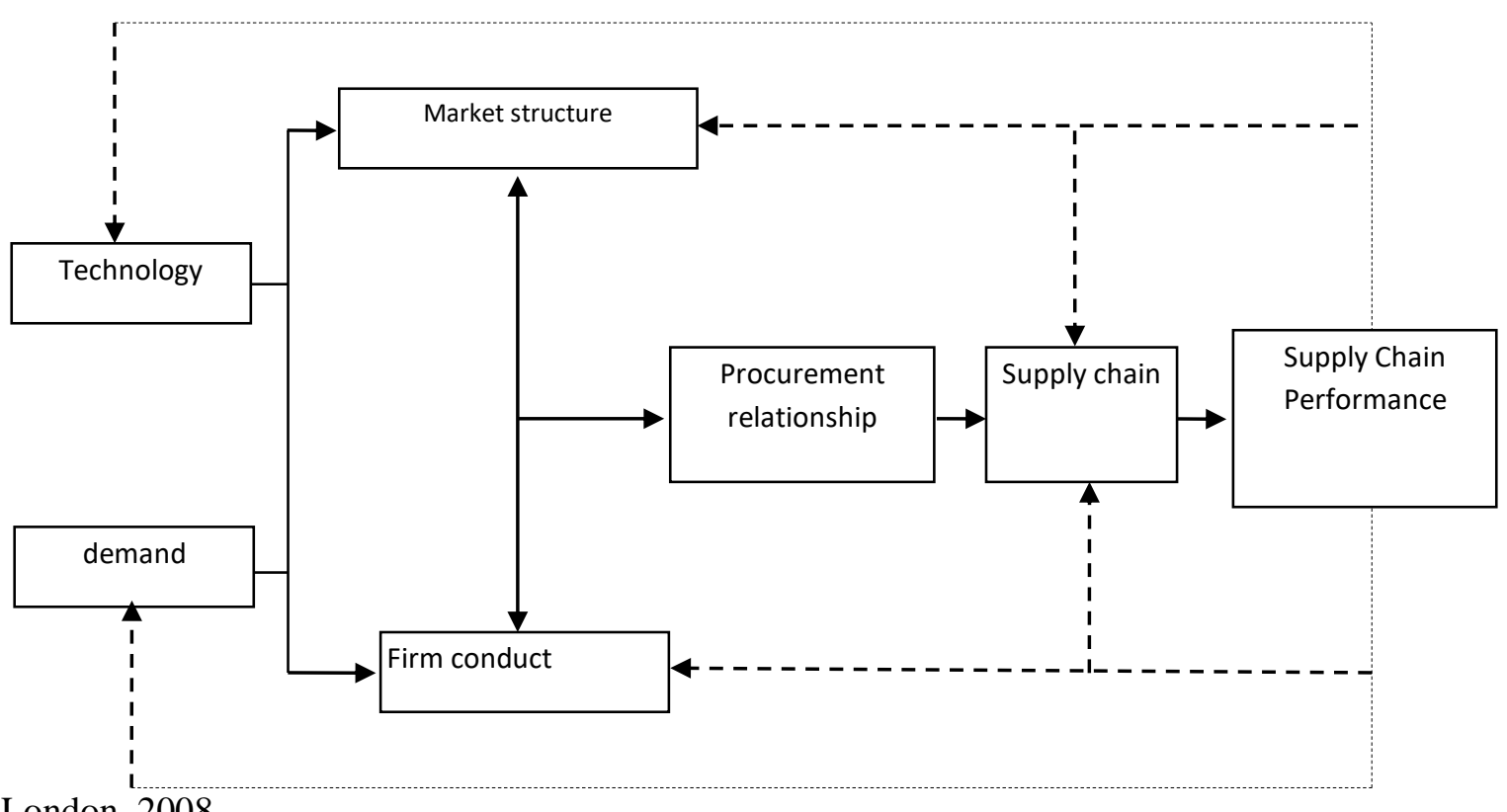

Sumber: London, 2008

Gambar Error! No text of specified style in document. Hubungan Konseptual Struktur, Perilaku dan Kinerja Rantai Pasok

Dalam jaringan rantai pasok konstruksi perilaku dapat didefinisikan dengan cara pelaku rantai pasok membangun jaringan atau bagaimana mereka berinteraksi. Suradji, Istijono dan Melani (2012) mendefinisikan perilaku dengan mengkaji hubungan interaksi pelaku rantai pasok konstruksi meliputi analisa tentang sitem pengadaan yang digunakan, bentuk ikatan perjanjian, sistem pembayaran dan lamanya interaksi antara kontraktor utama dengan jaringan rantai pasok dibawahnya. 


\section{METODE}

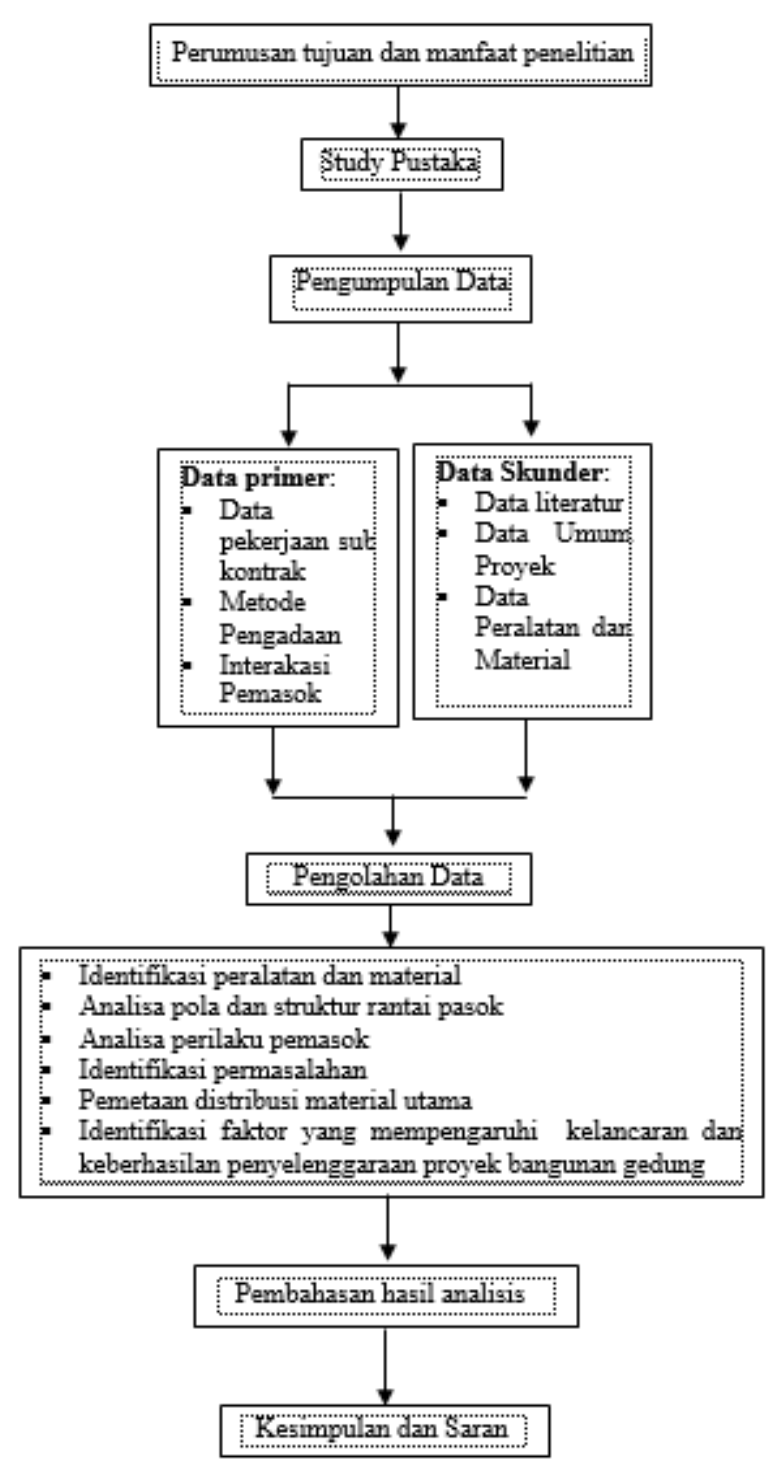

Gambar 4. Alur Penelitian

Penelitian dilakukan pada proyek konstruksi yang dilaksanakan di Kabupaten Tanah Datar yaitu proyek Pembangunan Gedung Fakultas Ekonomi dan Bisnis IAIN Batusangkar.

Informasi yang akan dikumpulkan adalah informasi yang berkaitan dengan antara lain:

1. Wawancara dengan pihak kontraktor pelaksana proyek yakni :

a. Gambaran umum proyek (data proyek dan ruang lingkup pekerjaan).

b. Data material dan peralatan yang digunakan dalam proyek.

c. Para pihak yang terlibat dalam rantai pasok konstruksi

d. Pendistribusian atau pembagian pekerjaan kepada organisasi proyek berdasarkan pola umum rantai pasok konstruksi.

e. Perilaku antara kontraktor utama dengan subkontraktor ditinjau dari metode pengadaan yang digunakan, cara pembayaran, pemilihan metode ikatan perjanjian yang tepat dan lamanya interaksi antara kontraktor utama dengan pelaku rantai pasok.

2. Informasi yang diperoleh dari wawancara dengan beberapa toko bangunan di Kota Batusangkar, Kota Padang Panjang dan Kota Padang tentang pola distribusi material utama bahan bangunan seperti semen, besi beton, triplek, paralon, cat, wastafel, keramik dan granit.

Analisa terhadap informasi yang diperoleh selanjutnya dilakukan langkah-langkah sebagai berikut:

1. Identifikasi peralatan dan material pada proyek konstruksi

2. Identifikasi pola dan struktur rantai pasok proyek konstruksi

3. Identifikasi perilaku pemasok dalam proyek konstruksi 
4. Identifikasi permasalahan dan faktor-faktor yang mempengaruhi keberhasilan proyek konstruksi.

\section{HASIL DAN PEMBAHASAN}

\section{Anasila Pola dan Sruktur Rantai Pasok Konstruksi}

Pola umum dalam Rantai Pasok Konstruksi dibedakan berdasarkan jenis pekerjaan yang dilakukan sendiri oleh kontraktor utama, pekerjaan yang diserahkan sepenuhnya kepada sub kontraktor termasuk penyediaan material dan peralatan ataupun pekerjaan yang diserahkan kepada tenaga kerja yang memiliki keterampilan khusus atau jenis pekerjaan yang diserahkan kepada subkontraktor spesialis. Pola khusus mencerminkan praktek pengadaan sub kontraktor dan kontraktor spesialis langsung dilaksanakan oleh pemilik.

Pola 1 : Pola pekerjaan yang langsung dilaksanakan oleh kontraktor utama dan kontraktor utama melakukan sendiri proses pengadaan material, alat dan pekerja.

Pola 2 : Pola pekerjaan dimana kontraktor utama memilih sub kontraktor untuk melaksanakan pekerjaan klasifikasi konstruksi umum serta klasifikasi konstruksi khusus yang tidak memerlukan perlengkapan khusus dengan pengadaan material, alat dan pekerja disediakan langsung oleh sub kontraktor.

Pola 3 : Pola pekerjaan dimana kontraktor utama menunjuk sub kontraktor spesialis untuk melaksanakan pekerjaan dengan klasifikasi konstruksi khusus yang memerlukan keahlian atau perlengkapan khusus, dengan peralatan, material dan pekerja langsung disediakan oleh sub kontraktor spesialis.

Pola 4 : Pola pekerjaan dimana kontraktor utama menunjuk kelompok pekerja untuk melaksanakan pekerjaan yang memerlukan keterampilan atau keahlian khusus, namun peralatan utama dan material masih diadakan langsung oleh kontraktor utama.

Pola 4 yang didefinisikan diatas merupakan pola baru yang penulis temukan di lapangan dan tidak didefinisikan dalam 3 konsep pola umum yang dikembangkan oleh Susilawati (2005).

\section{Proyek Gedung Fakultas Ekonomi dan Bisnis Islam IAIN}

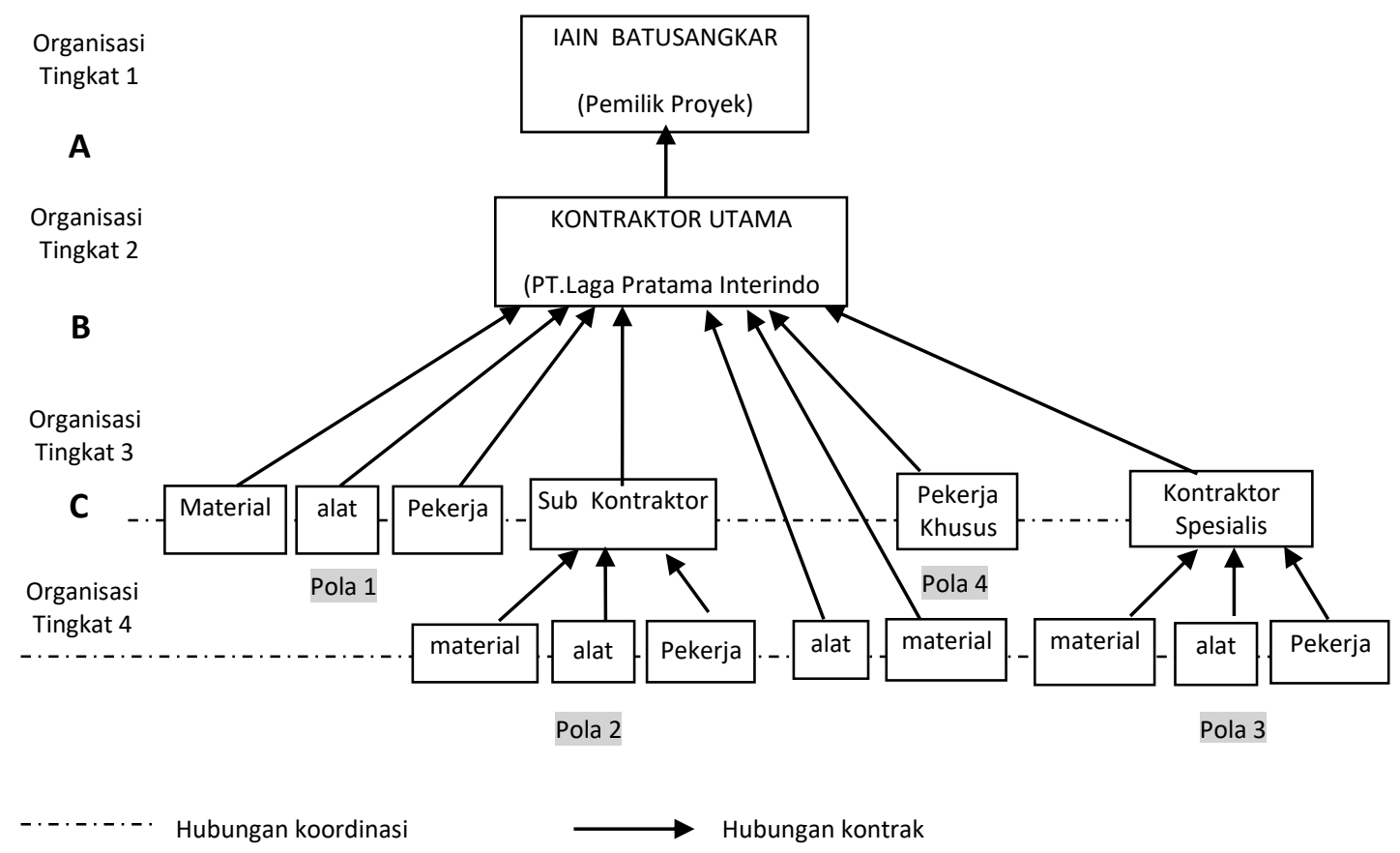

Sumber: data olahan, 2019

Gambar 5. Pola Rantai Pasok Konstruksi Proyek

Pola Hubungan Rantai Pasok yang teridentifikasi pada proyek ini adalah sebagai berikut:

Pola 1 : Terjadi pada item pekerjaan antara lain pekerjaan galian tanah, pekerjaan timbunan tanah, pekerjaan seng keliling, pekerjaan struktur beton bertulang (pekerjaan pengecoran beton, pekerjaan pembesian dan bekisting), pekerjaan lantai, pekerjaan dinding, pekerjaan plesteran, dan pekerjaan arsitektur.

Pola 2 : Terjadi pada item pekerjaan Mechanical Electrikal dan Plumbing, Pekerjaan Alumunium Composite Panel (ACP) Porporasi, Pekerjaan kuda-kuda baja ringan dan atap, pekerjaan railing tangga dan pekerjaan pasangan batu kali. 
Pola 3 : Terjadi pada pekerjaan Konstruksi Sarang Laba-Laba (KSLL) dan pekerjaan sumur bor.

Pola 4 : Terjadi pada pekerjaan pemasangan kaca stopsol, pemasangan kusen alumunium, pemasangan plafond, pengecatan, ukiran minang GRC, dan pekerjaan batu alam.

Pada proyek ini, owner selaku organisasi tingkat 1 hanya memiliki satu hubungan langsung dengan organisasi tingkat 2 yaitu kontraktor utama, selaku organisasi tingkat 2 kontraktor utama memiliki hubungan langsung ke organisasi tingkat 3 yaitu ke subsubkontraktor, pekerja khusus dan penyedia material, alat dan tenaga kerja serta hubungan ke organisasi tingkat 4 yaitu ke penyedia alat dan material untuk pekerjaan pemasangan kaca stopsol, pemasangan kusen alumunium, pemasangan plafond, pekerjaan pengecatan, pekerjaan ukiran minang GRC, dan pekerjaan batu alam.

Tabel 1. Nilai pekerjaan berdasarkan RPK pada Proyek

\begin{tabular}{|c|c|c|c|c|}
\hline $\begin{array}{c}\text { Pola } \\
\text { Pekerjaan }\end{array}$ & No & item pekerjaan & nilai pekerjaan $(\mathbf{R p})$ & bobot $(\%)$ \\
\hline \multirow{11}{*}{$\begin{array}{l}\text { Pekerjaan } \\
\text { dengan pola } 1\end{array}$} & 1 & galian tanah & $100.987 .935,00$ & 0,39 \\
\hline & 2 & timbunan tanah & $65.827 .600,00$ & 0,25 \\
\hline & 3 & pekerjaan seng keliling & $52.645 .362,00$ & 0,20 \\
\hline & 4 & pekerjaan pengecoran beton, pekerjaan pembesian, bekisting & 10.737.189.841,00 & 40,99 \\
\hline & 5 & Pekerjaan lantai & $383.621 .617,00$ & 1,46 \\
\hline & 6 & pekerjaan dinding batu bata & $75.622 .144,00$ & 0,29 \\
\hline & 7 & pekerjaan plesteran & $297.600 .985,00$ & 1,14 \\
\hline & 8 & Pekerjaan Permulaan & $169.768 .562,00$ & 0,65 \\
\hline & 9 & Pekerjaan Arsitektur & $5.167 .425 .592,00$ & 19,73 \\
\hline & 10 & Pekerjaan Site Development & $128.761 .434,00$ & 0,49 \\
\hline & & Total Nilai Pekerjaan Pola 1 & 17.179.451.072,00 & 65,58 \\
\hline \multirow{6}{*}{$\begin{array}{l}\text { Pekerjaan } \\
\text { dengan Pola } 2\end{array}$} & 1 & Pekerjaan Railing Tangga & $48.750 .000,00$ & 0,19 \\
\hline & 2 & Pekerjaan M/E dan Plumbing & $2.511 .771 .715,00$ & 9,59 \\
\hline & 3 & Pekerjaan Alumunium Composite Panel (ACP) Porporasi & $426.650 .000,00$ & 1,63 \\
\hline & 4 & Pek.kuda-kuda Baja Ringan/Atap & $270.741 .000,00$ & 1,03 \\
\hline & 5. & Pekerjaan Pondasi Batu Kali & $479.449 .022,00$ & 1,83 \\
\hline & & Total Nilai Pekerjaan Pola 2 & $3.737 .361 .737,00$ & 14,27 \\
\hline Pekerjaan & 1 & Pondasi KSLL & $3.902 .760 .000,00$ & 14,90 \\
\hline \multirow[t]{2}{*}{ dengan pola 3} & 2 & Pekerjaan Sumur Bor & $300.000 .000,00$ & 1,15 \\
\hline & & Total Nilai Pekerjaan Pola 3 & $4.207 .760 .000,00$ & 16,04 \\
\hline Pekerjaan & 1 & pekerjaan pemasangan kaca stopsol & $277.956 .007,00$ & 1,06 \\
\hline \multirow[t]{8}{*}{ dengan pola 4} & 2 & pemasangan kusen alumunium & $98.000 .000,00$ & 0,37 \\
\hline & 3 & pemasangan plafond gypsum board & $140.000 .000,00$ & 0,53 \\
\hline & 4 & pekerjaan cat dinding dan plafond & $493.058 .184,00$ & 1,88 \\
\hline & 5 & pekerjaan ukiran minang GRC & $29.328 .000,00$ & 0,11 \\
\hline & 6 & pekerjaan batu alam & $36.608 .000,00$ & 0,14 \\
\hline & & Total Nilai Pekerjaan Pola 4 & $1.074 .950 .191,00$ & 4,10 \\
\hline & & TOTAL SEBELUM PPN & 26.194.523.000,00 & 100,00 \\
\hline & & TOTAL TERMASUK PPN & $28.813 .975 .300,00$ & \\
\hline
\end{tabular}

Sumber: data olahan, 2019

Dari perbandingan pola pekerjaan terhadap nilai total masing-masing pekerjaan pada proyek A ini dapat diidentifikasi bahwa pola pertama merupakan pola yang paling banyak digunakan oleh kontraktor utama $65,58 \%$ persen secara berurutan pilihan selanjutnya adalah menggunakan pola ketiga $16,04 \%$, pola kedua $14,27 \%$ dan pola keempat $4,10 \%$.

\section{Analisa Perilaku Rantai Pasok Konstruksi}

Perilaku Rantai Pasok Proyek Konstruksi pada penelitian akan ditinjau dari sisi metode pengadaan rantai pasok, sistem pembayaran, bentuk ikatan perjanjian, bentuk hubungan antara pemasok dengan kontraktor utama, pengelolaan rantai pasok dalam jaringan pelaku rantai pasok serta langkah yang dilakukan agar hubungan jangka panjang pelaku rantai pasok dapat terpelihara.

\section{Metode Pengadaan Rantai Pasok pasok}

Berdasarkan hasil penelitian, proses pemilihan pemasok oleh kontraktor utama dikelola langsung di lapangan, tidak melakukan pengadaan di tingkat kantor pusat. Pengadaan material dalam jaringan rantai pasok pada umumnya menggunakan metode pengadaan langsung, yakni pengadaan dengan cara melakukan survey harga terlebih dahulu 
terhadap material yang dibutuhkan, sehingga akan didapatkan harga material yang wajar dan memenuhi spesifikasi teknis dari satu pemasok. Untuk pengadaan material tertentu seperti semen dilaksanakan secara langsung kepada distributor Semen Padang.

Berdasarkan hasil peta distribusi penyediaan material di Kabupaten Tanah Datar pemilihan rantai pasok material kontraktor utama lebih dominan memperoleh barang dari distributor yang berada di lokasi terdekat yaitu di Kota Padang Panjang dan Kota Padang. Hal ini dalam rangka memperoleh biaya yang efisien. Beberapa Toko Bangunan yang penulis wawancarai di kota Batusangkar sebagai lokasi terdekat proyek, tidak ada yang berperan sebagai distributor, melainkan hanya sebagai pengecer atau dalam istilah rantai pasok konstruksi ini ditulis sebagai supplier karena menyediakan barang dagangan. Dengan Metode Pengadaan langsung melalui distributor waktu pengiriman material juga akan lebih singkat, untuk pengiriman dari padang ke lokasi proyek hanya membutuhkan waktu 1-3 hari, sehingga secara umum penyediaan material dengan system jaringan rantai pasok yang dilaksanakan tidak terkendala dengan waktu maupun biaya, dan telah memilih siklus rantai pasok yang pendek karena lebih dominan memperoleh material dengan 2 tier. Proses pemesanan material disesuaikan dengan schedule kebutuhan bahan bangunan, sehingga pemesanan dilakukan berdasarkan adanya permintaan pelaksana lapangan dan koordinasi dengan bagian logistik untuk kelancaran pelaksanaan pekerjaan.

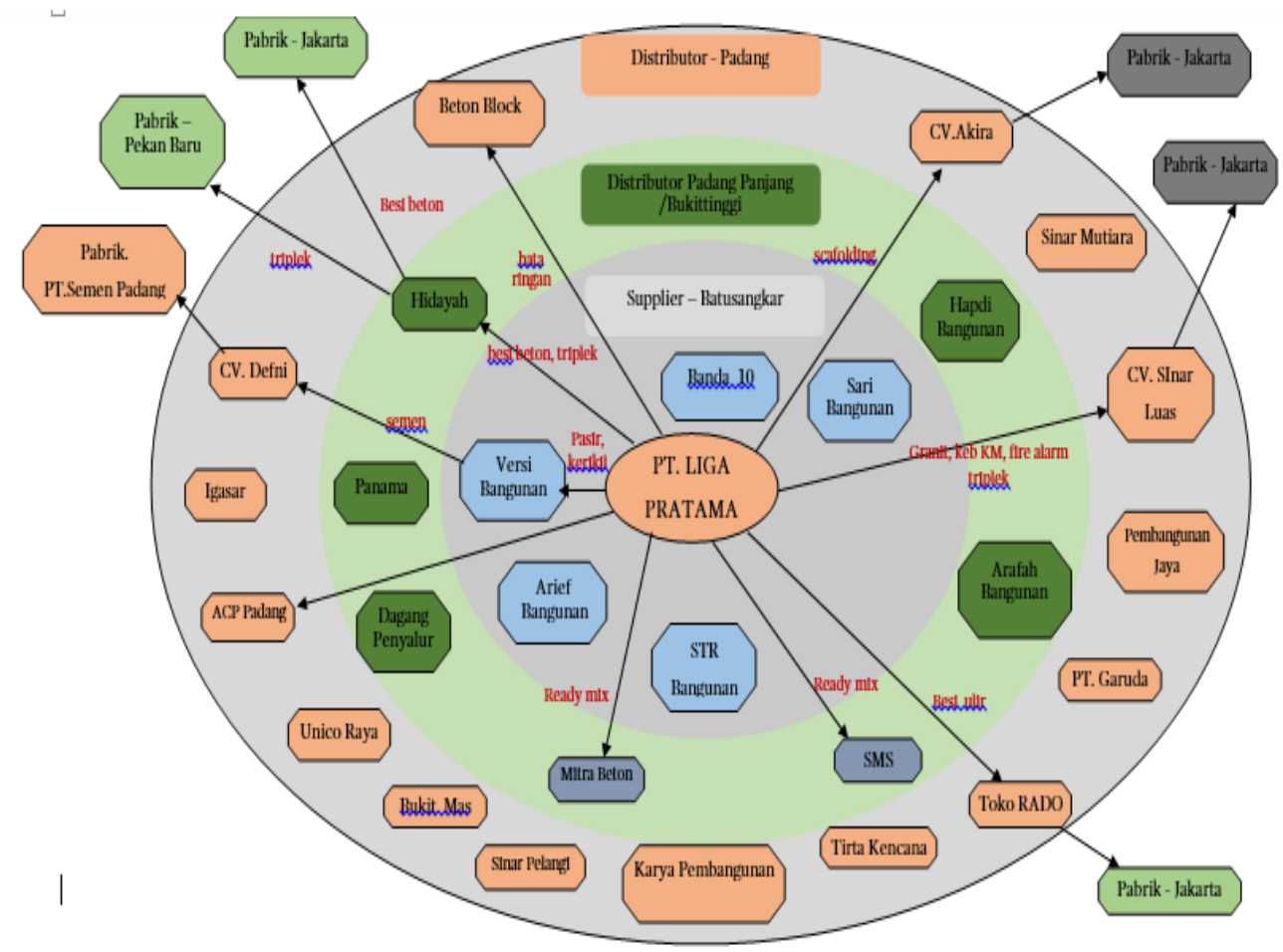

Sumber: Data Olahan, 2019

Gambar 6. Mapping Material Proyek

\section{Bentuk Ikatan Perjanjian (Kontrak Kerja)}

Bentuk Kontrak Kerja yang digunakan oleh Kontraktor Utama kepada Pemasok sebagai Sub Kontraktor/ Kontraktor Spesialis, maupun langsung dengan penyedia material adalah dengan metode kontrak harga satuan (fixed price contract). Metode ini dipilih dengan pertimbangan volume pekerjaan yang akan dilaksanakan masih dalam tahap perkiraan sedangkan harga satuannya sudah pasti dan tetap. Pembayaran atas prestasi pekerjaan disesuaian dengan volume barang/ pekerjaan yang telah diterima.

\section{Metode Pembayaran}

Secara umum metode pembayaran yang dipakai kontraktor dalam penelitian ini antara lain: Pembayaran secara tunai, metode ini digunakan kepada pemasok Beton Ready Mix dan beberapa distributor. Pembayaran dengan uang muka dan selanjutnya dibayar sesuai dengan progres kemajuan pekerjaan, terutama untuk pekerjaan yang di subkontrakkan pada pekerjaan Pondasi Konstruksi Sarang Laba-Laba (KSLL) dan biaya sewa scafolding. Pembayaran dengan termyn sesuai dengan jumlah barang yang diterima dan dapat dibayar kepada pemasok selambatnya selama 1 (satu) minggu setelah tagihan diterima, metode ini merupakan system pembayaran yang paling dominan digunakan oleh pelaku rantai pasok. 


\section{Strategi Pengelolaan Rantai Pasok oleh kontraktor utama}

Penerapan pengelolaan rantai pasok konstruksi dilakukan oleh kontraktor utama dalam bentuk:

1. Membina hubungan kerjasama dengan subkontraktor secara baik dan diteruskan dalam jangka panjang. Sebagian besar kontraktor utama memiliki pemasok/supplier yang telah lama berhubungan terutama kontraktor utama yang berdomisili di Kabupaten Tanah Datar. Dengan Komitmen membayar jasa tenaga kerja dan bahan material sesuai progres memberikan kepercayaan bagi semua pelaku rantai pasok konstruksi.

2. Koordinasi dengan supplier atau distributor dalam pengadaan material. Koordinasi sangat dibutuhkan, lokasi proyek dengan distributor ataupun supplier sangat mudah dijangkau oleh transportasi darat dan tidak membutuhkan waktu yang lama.

3. Mengelola ketersediaan dan penyimpanan material di lapangan. Dalam hal ini kontraktor utama mengupayakan agar tidak ada material yang terlalu berlebihan atau menumpuk di lapangan dan menyesuaikan dengan kondisi tertentu seperti penyimpanan besi beton atau semen tidak di tempat yang lembab. Kontraktor tidak memerlukan gudang yang besar karena permintaan material disesuaikan dengan waktu pemanfaatan material di lapangan.

Untuk menjamin terjadinya hubungan jangka panjang dengan pemasok material atau subkontraktor terdapat beberapa langkah yang diambil oleh semua pihak antara lain:

1. Kontraktor utama selaku pemberi tugas kepada subkontraktor melakukan pembayaran jasa hasil pekerjaan sesuai dengan perjanjian awal dan tepat waktu.

2. Pembayaran material oleh kontraktor utama kepada pemasok sesuai dengan kesepakatan dalam pemesanan, secara umum dibayarkan dengan system kredit jatuh tempo 1 minggu.

3. Seluruh item pekerjaan yang harus dilaksanakan ataupun terjadi perubahan di lapangan dituangkan dalam surat perjanjian sehingga fungsi pengawasan dan pertanggungjawaban pekerjaan dapat di monitoring bersama.

4. Pemasok ataupun subkontraktor bertanggungjawab terhadap kualitas barang atau hasil pekerjaan sesuai dengan spesifikasi yang ditentukan dalam surat perjanjian, agar hasil pekerjaan dapat dapat diterima oleh pemberi pekerjaan.

\section{SIMPULAN}

1. Terkait Pola Rantai Pasok Konstruksi dapat diperoleh kesimpulan sebagai berikut :

a. Pola yang digunakan pada proyek Konstruksi di Kabupaten Tanah Datar, menggunakan pola umum yakni kontraktor utama menggunakan pola 1 , pola 2 , pola 3 dan pola 4.

b. Pemilihan pola pekerjaan yang sering dipakai berdasarkan total nilai pekerjaan adalah menggunakan pola 1 dengan bobot diatas $50 \%$.

c. Terdapat pekerjaan dengan pola baru yakni pekerjaan pola 4 adalah pelaksanaan pekerjaan diserahkan sepenuhnya kepada tenaga kerja dengan keterampilan khusus dengan material dan peralatan utama disediakan oleh kontraktor utama.

2. Terkait Perilaku Rantai Pasok Konstruksi lokasi penelitian dapat diperoleh kesimpulan :

Metode Pengadaan material menggunakan metode pengadaan desentralisasi atau kewenangan penuh kontraktor di lokasi proyek sehingga proses pengadaan material lebih lancar dan efisien. Pengadaan material dominan dilakukan langsung ke distributor di kota Padang Panjang dan Padang sehingga terjadi siklus rantai pasok yang pendek.

a. Bentuk Ikatan Perjanjian antara pemilik proyek dengan kontraktor utama menggunakan jenis kontrak harga satuan, sedangkan dari kontraktor utama ke sub kontraktor dengan Surat Perintah Kerja (SPK), kepada penyedia material dengan surat pesanan.

b. Perilaku Rantai Pasok Konstruksi tidak dipengaruhi oleh Nilai Proyek, Lokasi Proyek ataupun waktu pelaksanaan proyek. Setiap proyek bangunan gedung unik dan memiliki perilaku yang ditentukan sendiri antara kontraktor utama dengan jaringan rantai pasok.

3. Keberhasilan proyek bangunan gedung dipengaruhi oleh 3 hal yaitu metode pemilihan pelaku rantai pasok, komitmen dan komunikasi yang efektif oleh semua pihak yang terlibat dalam rantai pasok konstruksi.

4. Dengan penerapan pengelolaan rantai pasok konstruksi, seluruh pekerjaan pada lokasi proyek yang diteliti selesai dilaksanakan oleh kontraktor utama sampai dengan bobot 100 (seratus) $\%$ dan tidak terdapat permasalahan yang berarti.

\section{Saran}

1. Untuk mendapatkan informasi pola dan struktur rantai pasok konstruksi yang lebih beragam, perlu dilakukan penelitian pada bangunan gedung yang dilaksanakan oleh non pemerintah atau swasta.

2. Penelitian selanjutnya dapat difokuskan kepada peran owner (pemilik proyek) sejak awal perencanaan dalam penyelenggaraan rantai pasok konstruksi pada poyek bangunan gedung. 


\section{DAFTAR PUSTAKA}

Abduh, Muhammad,2012. Rantai Pasok Konstruksi Indonesia, Buku Konstruksi Indonesia 2012, Kementerian PU Republik Indonesia, Jakarta.

Abduh, Muhammad,2007. Konstruski Ramping untuk mencapai konstruksi yang berkelanjutan.

Bahagia, Senator Nur,2012."Harmonisasi Rantai Pasok Konstruksi, Buku Konstruksi Indonesia 2012”,Jakarta.

Budiman, Ade surya, 2017. Kajian Penerpan EDI dalam Pengelolaan Rantai Pasokan di Industri Manufaktur, Jurnal Ilimiah Teknologi Informasi Terapan, Volume III, Nomor 3, 30 Agustus 2017, halaman 249-260.

Christoper, Martin, 2011, Logistics and Supply Chain Management, Fourth Edition.

Dei, K.Aditya,Darmayanti dan Martha Jaya. Analisis Risiko dalam Aliran Supply Chain Pada Proyek Konstruksi Gedung di Bali, Jurnal Spektran, Volume 5 No1, January 2017, halaman 1-82.

Ibrahim.MA, "Metodologi Penelitian Kualitatif', 2015

Kamus Besar Bahasa Indonesia, https://kbbi.web.id/, 2017

Kirmanto, Joko, 2012.Harmonisasi Rantai Pasok Konstruksi, Buku Konstruksi Indonesia 2012, Kementerian PU Republik Indonesia, Jakarta

Maulani, Febiani dan Suraji, Akhmad dan Istijono, Bambang, 2014. "Analisis struktur Rantai Pasok Konstruksi pada pekerjaan Jembatan, Jurnal Rekayasa Sipil, Volume 10 no.2, Oktober 2014, halaman 1-8.

Mursadin, Aqli, 2011. Kajian Sistem Pasokan Berasis Lean Construction pada proyek-proyek Konstruksi di Balik Papan", Jurnal Teknologi Berkelanjutan, Vol 1 edisi 1 April 2011 1-10, halaman 53-62.

Mustika,2011,"Hubungan Antara Kinerja, Intensitas Dan Bentuk Rantai Pasok Pada Proyek Bangunan Bertingkat Di Jakarta",Jakarta.

Oktaviani, 2008."Kajian Kinerja Supply Chain Pada Proyek Konstruksi Bangunan Gedung”, Bandung.

Natsir, Muhammad, 2015, "Sistem Rantai Pasok Material dan Peralatan Konstruksi untuk mendukung Investasi Infrastruktur", Bandung.

Peraturan Kepala Badan Pusat Statistik Nomor 19 Tahun 2017 Tentang Perubahan Atas Peraturan Kepala Badan Pusat Statistik Nomor 95 Tahun 2015 tentang Klasifikasi Baku Lapangan Usaha Indonesia.

Peraturan Menteri Pekerjaan Umum Nomor 8/PRT/M/2011 tentang Pembagian Subklasifikasi dan Subkualifikasi Usaha Jasa Konstruksi.

Peraturan Pemerintah Republik Indonesia Nomor 29 tahun 2000 tentang Penyelenggaraan Jasa Konstruksi.

Peraturan Presiden Nomor 54 Tahun 2010 tentang pengadaan Barang dan Jasa Pemerintah sebagaimana telah beberapa kali diubah terakhir dengan Peraturan Presiden Nomor 4 Tahun 2015 tentang Perubahan Keempat Peraturan Presiden Nomor 54 Tahun 2010.

Pandarangga,Adi; Wibowo, M.Agung; Dwihatmoko, Jati Utomo, 2015, "Studi Pola Rantai Pasok Konstruksi pada proyek Jalan dan Jembatan Kabupaten (Studi Kasus pada Dinas Pekerjaan Umum Kabupaten Sumba Timur)", 2015 ,

Poerwanto,Hendra,https://sites.google.com/site/operasiproduksi/manajemen-rantai-pasokan, 2011 diakses tanggal 1 November 2017

Pribadi, Khrishna, 2007, "Identifikasi Rantai Pasok dalam Industi Konstruksi Indonsia untuk Pengembangan Sistem Manajemen Mutu", Bandung.

Reini D.Wirahadikusumah dan Susilawati ,2006. "Pola Supply Chain pada proyek Konstruksi Bangunan Gedung, Jurnal Teknik Sipil Volume 13 Nomor 3 , halaman 107 - 123.

Richard,2007. "Studi Penerapan Manajemen Rantai Pasok Pengadaan Material Proyek Konstruksi”, Jurnal Teknik Sipil halaman 217-223.

Suisilawati dan Reini D.Wirahadikusumah, 2006. "Kajian Pengadaan oleh Kontraktor Pelaksana pada Proyek Konstruksi Bangunan Gedung”, Jurnal Teknik Sipil, Volume 13 No 3 Juli 2006.

Soephiady,Sutoyo, 2011, "Pengaruh Rantai Pasok terhadap Kinerja Kontraktor Bangunan Gedung di Jember", Jurusan Teknik Sipil FTSP ITS.

Sugiyono. (2012). Metode Penelitian Kuantitatif dan Kualitatif, Yogyakarta

Suradji, Akhmad, dkk, 2014, "Analisis Struktur Rantai Pasok Konstruksi pada Pekerjaan Jembatan”. Jurnal Rekayasa Sipil, Volume 10 No.2,halaman 1-8. 